\title{
Maximization of arable crop yields in the Netherlands
}

\section{Sibma}

Centre for Agrobiological Research, Wageningen, the Netherlands

Accepted: 27 June 1977

Key words: potential production, light interception, crop growth rate

\section{Summary}

The yields in $\mathrm{kg}$ per ha were calculated of potatoes, sugar-beets and winter wheat for conditions under which water and mineral supply were not limiting growth rates.

These studies showed that the time at which a closed crop canopy can be obtained in spring, is an important criterion for the yield.

Growth analyses of maize and sugar-beets confirm that relatively high yields can still be improved by accelerating leaf development in spring.

\section{Introduction}

In the Netherlands average yields of arable crops are on a high level and still increase annually. Comparison of farm results showed that these physically high yields are due rather to applied experience on the correct cultivation measures, fertilizer application, disease control, choice of varieties, etc. (Zachariasse, 1974) than to the application of growing quantities of energy and labour (de Wit, 1975).

It will be interesting to know to what extent the average yields can be further increased with the materials and methods available at present, when water and mineral supply are not limiting. Another point of interest is whether the calculated yields at optimum water and mineral supply can be further increased.

\section{Potential production rate}

In calculating the highest possible (i.e. potential) production rate, a green, closed crop canopy is assumed optimally supplied with water and minerals. Growth rate of this simulated crop is determined by the quality of the closed crop canopy and the incoming radiation.

De Wit (1965, page 33) calculated for such a crop under standard conditions the maximum gross production for each 10th degree of latitude on earth. For the middle of each month the radiation in cal $\mathrm{cm}^{-2}$ day-1 $^{-1}(400-700 \mathrm{~nm}), \mathrm{H}_{\mathrm{c}}$, and the production in $\mathrm{kg}$ of dry matter ha-1 day-1, $\mathrm{P}_{\mathrm{c}}$, have been tabulated. Both values apply to a cloudless sky. Radiation from an overcast sky is supposed to be 0.2 of that on a 
clear day. The relevant production in $\mathrm{kg}$ of dry matter ha- $\mathrm{a}^{-1}$ day-1 is $\mathrm{P}_{0}$. The basic data of de Wit (1965) for $\mathrm{H}_{\mathrm{c}}, \mathrm{P}_{\mathrm{c}}$ and $\mathrm{P}_{0}$ values have been interpolated by Rijtema \& Endrödi (1970) for $52^{\circ} \mathrm{N}$.

Following the procedure of de Wit with the values for $H_{c}, \mathbf{P}_{c}$ and $\mathbf{P}_{0}$ found by Rijtema the gross production rate in $\mathrm{kg}$ of dry matter ha- $\mathrm{h}^{-1}$ has been calculated with the equation $\mathrm{P}=\mathrm{FP}_{0}+(1-\mathrm{F}) \mathrm{P}_{\mathrm{c}}$ in $52^{\circ} \mathrm{N}$ for the middle of each month. Where $\mathrm{F}$ is $\left(\mathrm{H}_{\mathrm{c}}-\mathrm{H}_{\mathrm{a}}\right) / 0.8 \mathrm{H}_{\mathrm{c}}, \mathrm{H}_{\mathrm{a}}=0.5 \mathrm{H}_{\mathrm{sh}}$, and $\mathrm{H}_{\mathrm{sh}}$ the average of the daily global radiation in cal cm ${ }^{-2}$ day $^{-1}$ at Wageningen from 1931-1966. The values obtained for the gross production rate have been recapitulated in Fig. 1 as line 1.

Gross production rate means that the respiration required in maintenance and internal translocation has not been taken into account.

\section{Radiation from the sun intercepted by arable crops}

The total annual production of an arable crop with optimum water and mineral supply is among others dependent on the amount of sun energy intercepted by that crop during the growing period (Sibma, 1970). Light intensity, the properties of the crop surface and the duration of the field period of the crop determine the total amount of energy intercepted by it.

To collect data on the duration and the extent to which the light is intercepted by arable crops, in 1970 regular measurements were carried out with photo cells above and under the leaf canopy of potatoes, beets and wheat. Well-tended crops were taken for this, grown at the experimental farm 'De Lovinkhoeve' in the Northeast Polder, exploited by the Institute for Soil Fertility (IB) at Groningen.

With respect to these observations it is stated that the potato and winter wheat crops were not measured throughout the growing period. In potatoes the first part of the light interception was estimated by taking 15 May as the date of emergence and 15 June as the date on which the soil was completely covered by foliage. In sugar-beets 1 May was taken as the date of emergence and 20 June as the date of complete soil coverage. In winter wheat soil coverage before 1 April was negligible, before this date temperature is limiting growth. After 31 July it has been assumed that the green leaf surface gradually decreases until 15 August. A possible overestimation of light interception due to dying and dead leaves intercepting part of the light at the end of the growing season is negligible for the different crops.

Light interception in percentages by potatoes, sugarbeets and wheat is reflected in Fig. 1 by line 2. The dates on which the observations were made have been indicated by a dot on line 2 .

\section{Calculated growth rate and annual yield}

The growth rate of arable crops is not limited by temperature between 1 May and 1 October and should be equal to that of the standard crop in $52^{\circ} \mathrm{N}$, as indicated by line 1 in Fig. 1. It is required, however, that the crop be disease-free, water and mineral supply be at an optimum and light interception almost $100 \%$.

Line 2 in Fig. 1 shows that the latter demand, complete light interception, is not always met by all the crops. Insufficient light interception, especially in sugar-beets, was found to be an important limitation to the growth rate in spring. 
L. SIBMA
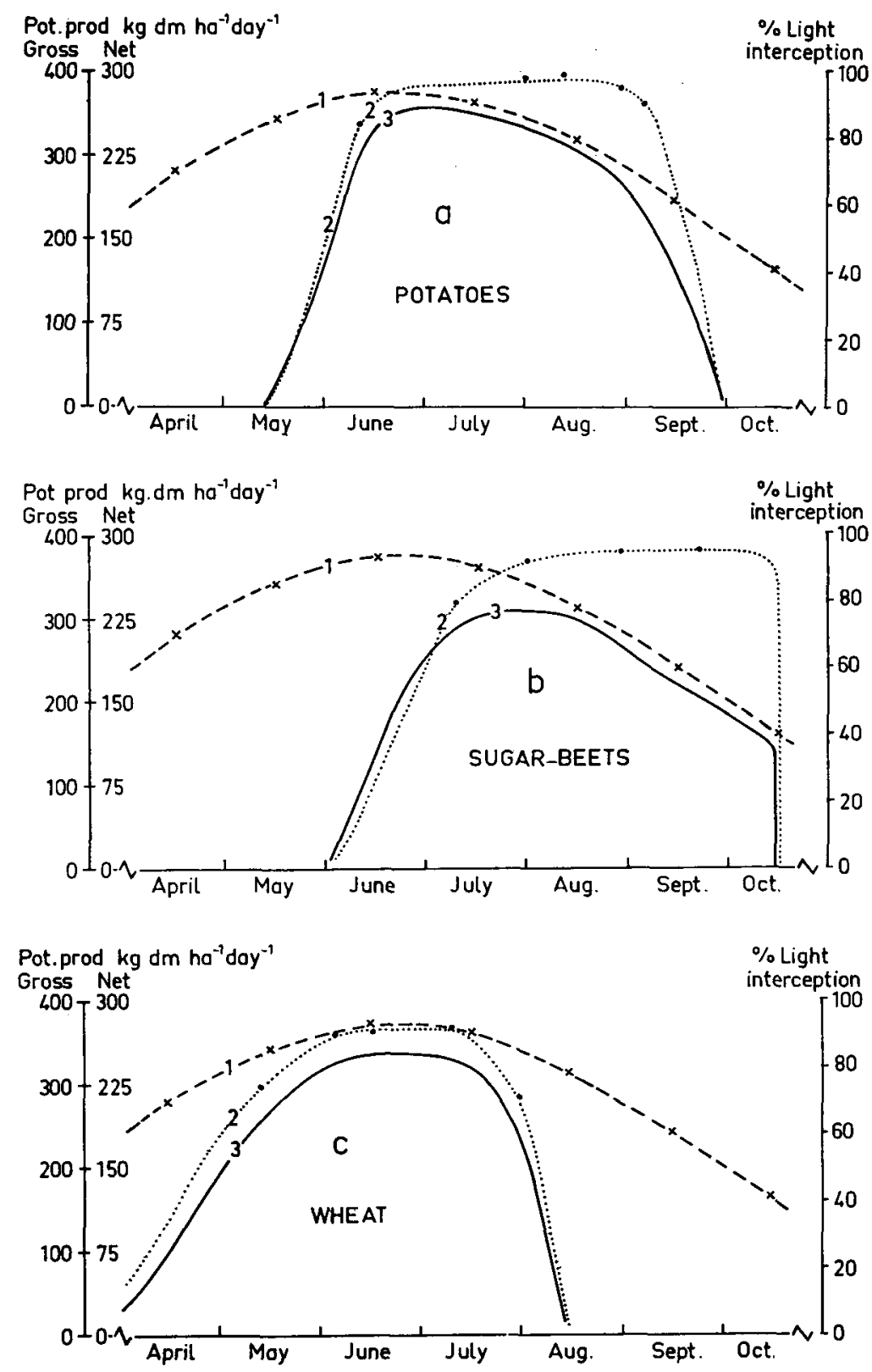

Fig. 1. Potential gross production rate (line 1), percentage of light intercepted by the crop (line 2) and calculated crop growth rate (line 3) of potatoes, sugar-beets and wheat. 
For this reason, light interception was used as a conversion factor to calculate the growth rate of potatoes, beets and wheat from the growth rate of the standard crop. A linear relationship was assumed between the rate at which a crop intercepts the light and its growth rate with respect to the standard crop. The growth rates to be found on line 1 were multiplied by the percentage of intercepted light on line 2 . The product of this multiplication is reflected as line 3 and indicates the gross production in $\mathrm{kg}$ dry matter $\mathrm{ha}^{-1} \mathrm{day}^{-1}$ for the relevant crop. Integration of line 3 shows the gross yield of the crops in terms of $\mathrm{kg}$ of dry matter ha- $\mathrm{h}^{-1}$ at the end of the growing season. These values of the three crops have been mentioned in Table 1 as the gross production in $\mathrm{kg}^{\prime}$ of dry matter $\mathrm{ha}^{-1}$ year-1. $^{-1}$.

Since de Wit (1965) calculated gross photosynthesis rates respiration should be subtracted before arriving at actual dry matter yields.

Fig. 2 shows respiration rates in $\mathrm{kg}$ of $\mathrm{CH}_{2} \mathrm{O} \mathrm{ha}{ }^{-1} \mathrm{~h}^{-1}$ in dependence on the temperature in the canopy of closed potato crops in 1973 and 1975 (Bodlaender, personal comm.), measured with a mobile installation (Louwerse \& Eikhoudt, 1975).

In July when maximum foliage is attained, above-ground respiration may also be considered to be at a maximum. At a mean temperature of $18{ }^{\circ} \mathrm{C}$ in July, the maximum above-ground respiration is $24 \times 3.5 \mathrm{~kg}=84 \mathrm{~kg}$ of $\mathrm{CH}_{2} \mathrm{O}$ per ha per $24 \mathrm{~h}$. Above-ground respiration has to be increased with that of the tubers.

Winkler (1970) established the respiration losses of the tuber sizes $1-2 \mathrm{~cm}, 2-3 \mathrm{~cm}$ and $3-5 \mathrm{~cm}$ diameter at $0.82,0.42$ and $0.38 \mathrm{mg}$ of dry matter per gramme of tuber dry matter per hour. These respiration rates applying to the amount of tubers present in a good potato crop in July, show that the respiration of tubers is 10 to $20 \mathrm{~kg}$ of $\mathrm{CH}_{2} \mathrm{O} \mathrm{ha}^{-1}$ per $24 \mathrm{~h}$. The total respiration at a maximum is $84+20=104 \mathrm{~kg}$ $\mathrm{ha}^{-1}$ day $^{-1}$. Line 1 in Fig. 1 indicates for gross photosynthesis in July $360 \mathrm{~kg}$ of dry matter ha $\mathrm{a}^{-1}$ day-1. Respiration in terms of gross photosynthesis therefore amounts to $28.8 \%$. Winkler calculated from his own data for the month of July

Table 1. Annual gross production of potatoes, sugar-beets and wheat calculated to net dry matter and fresh weight production

\begin{tabular}{|c|c|c|c|}
\hline & Potatoes & Sugar-beets & Winter wheat \\
\hline Gross production (kg DM ha-1 year-1) & 35082 & 36200 & 32552 \\
\hline Respiration (kg DM ha-1 year $^{-1}$ ) & 8770 & 9050 & 8138 \\
\hline Total dry matter $\left(\mathrm{kg} \mathrm{DM} \mathrm{ha}^{-1}\right.$ year $\left.^{-1}\right)$ & $\overline{26312}$ & $\overrightarrow{27150}$ & $\overline{24414}$ \\
\hline Fallen leaves $\left(\mathrm{kg} \mathrm{DM} \mathrm{ha}^{-1}\right.$ year-1) $\left.^{-1}\right)$ & 1500 & 2000 & 500 \\
\hline Harvested dry matter ${ }^{1}\left(\mathrm{~kg} \mathrm{DM}\right.$ ha $^{-1}$ year $^{-1}$ & $\overline{24812}$ & $\overline{25150}$ & $\overline{23914}$ \\
\hline Main product $(\%)$ & 85 & 67 & 40 \\
\hline Main product $\left(\mathrm{kg} \mathrm{DM} \mathrm{ha}^{-1}\right.$ year $\left.^{-1}\right)$ & 21090 & 16850 & 9566 \\
\hline Dry matter in main product $(\%)$ & 22 & 22 & 85 \\
\hline Main product $\left(\mathrm{kg} \mathrm{ha}^{-1}\right.$ year $\left.^{-1}\right)$ fresh & $\begin{array}{c}95862 \\
(82307)\end{array}$ & $\begin{array}{c}76590 \\
(65569)\end{array}$ & 11254 \\
\hline
\end{tabular}

1 Including roots.

2 Main product when respiration is $35 \%$ of the gross photosynthesis. 


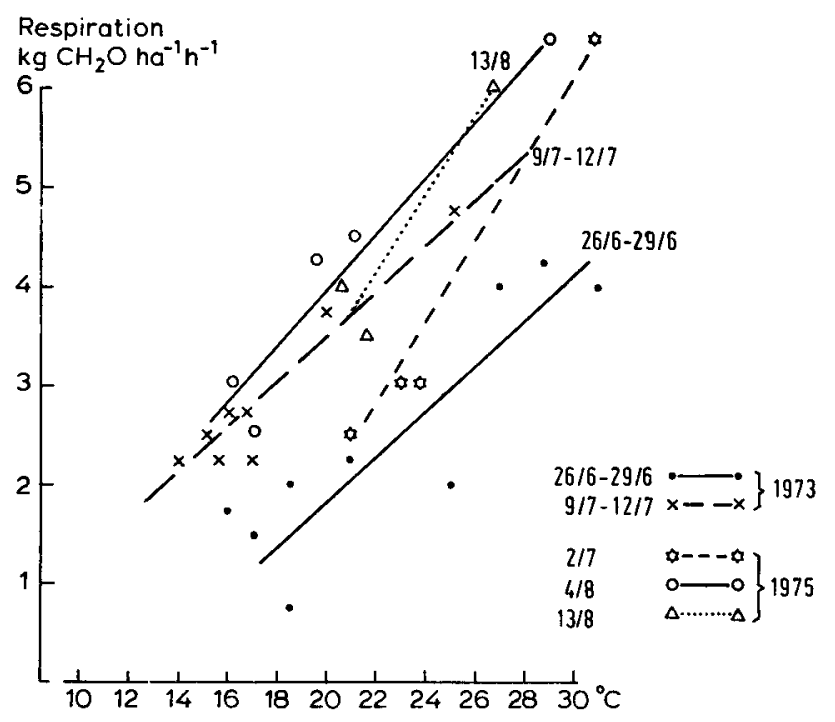

Fig. 2. Relation between temperature and respiration in $\mathrm{kg} \mathrm{CH}_{2} \mathrm{O} \mathrm{ha-1} \mathrm{h}^{-1}$ of potato crops in 1973 and 1975 in succeeding stages of growth.

30 to $40 \%$ of the net photosynthesis which corresponds to about 25 to $35 \%$ of the gross photosynthesis. Burton (1964) states that respiration of potatoes is $25 \%$ at a maximum.

In 1973 and 1974 de Vos assessed respiration in winter wheat varieties at $18{ }^{\circ} \mathrm{C}$ at $5 \mathrm{~kg}$ of $\mathrm{CH}_{2} \mathrm{O} \mathrm{ha}^{-1} \mathrm{~h}^{-1}$ which means $120 \mathrm{~kg}$ of $\mathrm{CH}_{2} \mathrm{O}$ ha- per $24 \mathrm{~h}$ (Alberda et al., 1977). With some root respiration this means $35 \%$ of respiration. Since the average temperature can assumed to be lower than $18{ }^{\circ} \mathrm{C}, 25 \%$ of respiration was assumed in Table 1 to calculate the net production. The same calculation was repeated for a respiration of $35 \%$. Only the final result of the latter calculation, between brackets, has been mentioned in Table 1 .

Bodlaender \& Algra (1966) established that at very high production levels of potatoes $85 \%$ of the total dry matter in over- and underground parts was embedded in the main product (tubers), and about $1500 \mathrm{~kg}$ of dry matter disappeared in the falling leaves. In sugar-beets at normal distance it was established that $67 \%$ of the total harvested product consisted out of beets (Houba, 1973). For replacement of old leaves a dry matter loss of $2000 \mathrm{~kg}$ was assumed in this crop. After ripening of winter wheat about $40 \%$ of the total dry matter consists out of grains (van der Zweerde, 1968; Jonker, 1958). It was assumed that $500 \mathrm{~kg}$ of dry matter per ha was lost in falling leaves not harvested. These data are averages for well-growing crops.

Table 1 shows the remaining main product in kg of dry matter per ha, after subtracting the losses for respiration, loss of leaves and additional products from the gross production. Next these calculated amounts of dry matter have been converted 
to fresh weights in $\mathrm{kg} \mathrm{ha}^{-1}$ of potatoes and beets and to storable product of winter wheat, with the indicated dry matter percentages. At the bottom of Table 1 the amount of main product has been mentioned between brackets in $\mathrm{kg} \mathrm{ha}^{-1}$, with a respiration of $35 \%$ of the gross photosynthesis with otherwise the same calculation procedure.

With optimum management yields of 95 (metric) tons of potatoes, 76 tons of sugar-beets and 11 tons of wheat are feasible in a year with average radiation. With $35 \%$ of respiration these amounts are 82 tons, 65 tons and 10 tons, respectively.

\section{Leaf development in spring}

Comparison of the curve indicating potential production (line 1) with that of light interception (line 2) shows that the maxima of both lines coincide much better with wheat than with sugar-beets. In the latter crop light interception (see Fig. 1b) only attains its maximum when potential growth rate is already decreasing. In the period of great potential possibilities growth of sugar-beets is negligible because a crop canopy is lacking. When the leaf canopy has attained its full size, roundabout the last decade of June, the potential production level will decrease, limiting actual growth more and more. The latter process cannot be changed, but the date at which a closed canopy is attained in the field can be influenced. Advancing this moment will affect the yield of beets favourably.

The same can be said for maize. Slow spring development will be the cause that too little sun energy is intercepted in May and June to be used in the formation of dry matter, due to the lack of a closed green leaf canopy. Accelerating the date on which maize has formed a closed crop canopy should affect the final yield favourably.

With some field experiments with sugar-beets and maize a study was made to see if the development of the leaf canopy distinctly affects the yields of these crops.

\section{Experiments}

On 25 April 1975 silage maize of the cv. Cappela was sown at a row distance of $75 \mathrm{~cm}$ on moisture containing sandy soil at Wageningen. Before sowing the field was fertilized with $125 \mathrm{~kg} \mathrm{P}_{2} \mathrm{O}_{5} \mathrm{ha}^{-1}$ (basic slag) in November, $160 \mathrm{~kg} \mathrm{~K}_{2} \mathrm{O} \mathrm{ha}^{-1}$ (K40) in March, 20 tons of slurry +30 tons of farmyard manure and $150 \mathrm{~kg} \mathrm{~N}$ $\mathrm{ha}^{-1}$ (ammonium nitrate limestone) in April. Immediately after sowing transparent plastic tunnels of $40 \mathrm{~cm}$ wide and $20 \mathrm{~cm}$ high were placed lengthwise over the rows in order to stimulate emergence and first leaf development $(\mathrm{Pl}+)$ and for comparison control treatments without plastic covers (Pl-). The plastic was stretched over bent tubes placed across the rows and removed on 20 May. The control treatments were in triplicate on plots of $4 \mathrm{~m} \times 1.5 \mathrm{~m}=6 \mathrm{~m}^{2}$. Under otherwise similar conditions also hand-planted maize was compared. Only the plant distance in the row was somewhat more accurate here.

In 1976 this latter treatment was discontinued, but the experiment was extended. In this way a relatively early cultivar, Cappela, and a late cultivar, P 3853 , could be harvested periodically, to compare the growth of both varieties with and without 
plastic covers. Spring dressing was similar to 1975 ; before emergence $2 \mathrm{~kg}$ of atrazine was sprayed in both years.

In 1976 in the same way emergence and first growth were stimulated in the sugarbeet, cv. Monohil, on sandy clay soil in the Northeast Polder. Some days after sowing on 23 March, small tunnels of $25 \mathrm{~cm}$ wide and $12.5 \mathrm{~cm}$ high were placed over the rows. Row distance was $50 \mathrm{~cm}$ and plant distance $17 \mathrm{~cm}$ in the row. On 5 March $80 \mathrm{~kg} \mathrm{~N} \mathrm{ha}^{-1}$ (calcium nitrate), on 17 May $50 \mathrm{~kg} \mathrm{ha}^{-1}$ (calcium nitrate) and on 26 May $50 \mathrm{~kg} \mathrm{~N} \mathrm{ha}^{-1}$ (ammonium nitrate limestone) was applied.

In 1976 the sugar-beet experiments were sprinkled once and those of maize more times.

\section{Results}

Regularity in plant size was not affected by the presence of plastic tunnels. Emergence was stimulated only very slightly, but the treatment did stimulate leaf growth after emergence.

When the plastic tunnels were removed in the beets on 6 May and in the maize on 20 May, the leaf area index (LAI; $\mathrm{m}^{2}$ leaves per $\mathrm{m}^{2}$ soil) was advanced, as shown in the Fig. 3. The first dry matter yields were so low, that differences were not evident, as reflected in Fig. 4.

Fig. 4 shows that between the first and the second observation the difference in dry matter yield had increased. Better light interception caused by more rapid leaf development under the plastic tunnels was responsible for a higher growth rate after removing the plastic. These actual growth rates in $\mathrm{kg}^{\mathrm{d} y}$ matter $\mathrm{ha}^{-1} \mathrm{day}^{-1}$ between two harvests are presented upon the growth curves.

The observation data in the third decade of July show that LAI $\geqslant 4$, which indicates that the crop canopies have been closed for some time and do not limit growth rate. After this date a difference in growth rate is not to be expected until
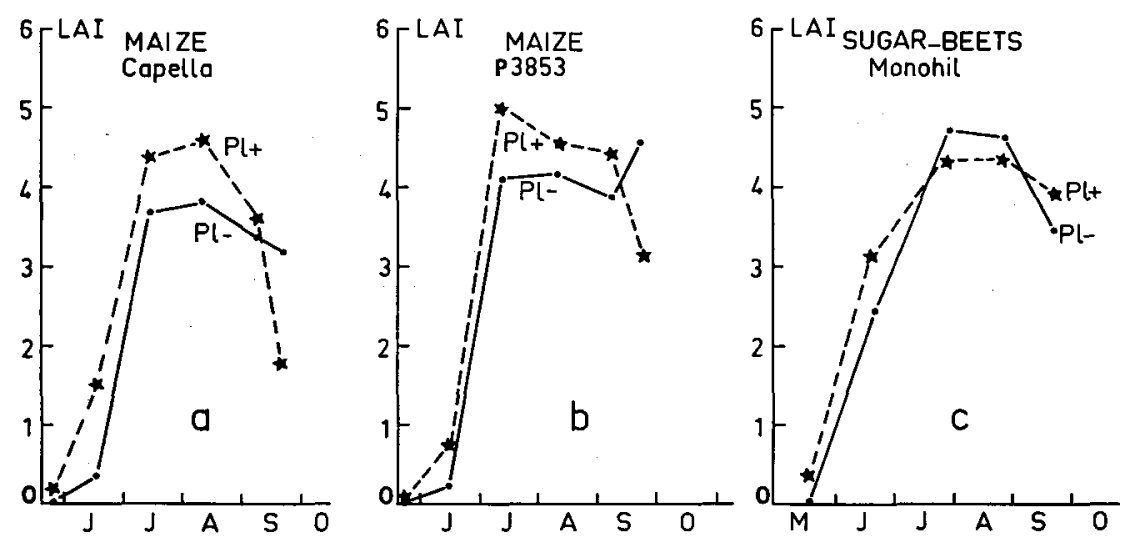

Fig. 3. Leaf area index (LAI) of two maize varieties and sugar-beets emerged and grown during some weeks under plastic $(\mathrm{Pl}+)$ and control (Pl-). 


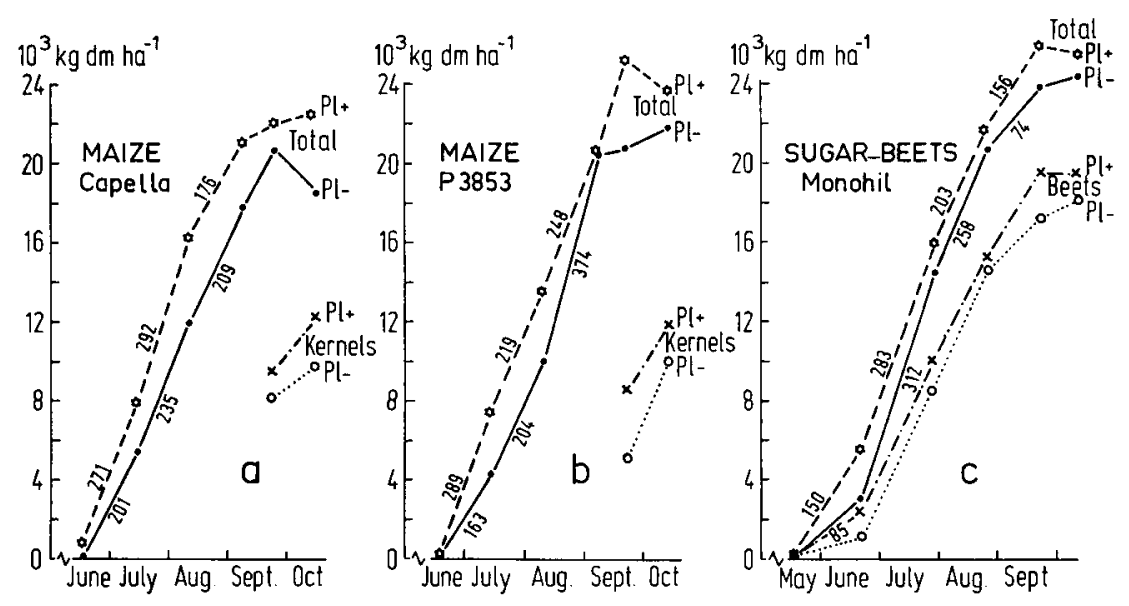

Fig. 4. Dry matter yields of two maize varieties and sugar-beets emerged and grown during some weeks under plastic $(\mathrm{Pl}+)$ and control $(\mathrm{Pl}-)$. Numerals upon the growth curves indicate crop growth rate in $\mathrm{kg} \mathrm{dm} \mathrm{ha-1}^{-1} \mathrm{day}^{-1}$ for the concerning period.

senescence begins, which is accelerated in maize by the presence of plastic (see Fig. $3 a$ and $3 b)$.

The yields of the last two harvests have been summarized in Table 2 , in such a way that a treated plot $(\mathrm{Pl}+)$ is comparable to an untreated plot (P1-). With respect to the main product, all the yields were increased by $\mathrm{PI}+$ and the relation main product : total, was improved.

\section{Discussion}

Comparison of Fig. 1a, Fig. 1b and Fig. 1c (line 2 and 3) demonstrates that there are slight differences in the duration of growth of the crops taken as an example, but that the time in which they grow differs more widely. Because of the lower heat requirement of wheat, this crop forms a closed green canopy much earlier in spring than sugar-beets and potatoes. Therefore wheat grows in a period that the potential production level is high. The relatively early ripening of the crop limits the yield. From Fig. 1c it can be inferred that the duration of growth can be prolonged by earlier soil coverage as well as by prolonging the period of grain formation. Top dressing and adequate disease control at the end of the growing period are the measure by which is tried to achieve this effect already now.

In sugar beets, however, prolonging growth at the end of the growing period is hardly effective, since the potential production level is too low, then. Acceleration of reaching a closed canopy is effective, because not only the growth duration is prolonged, but also the crop is present when the potential production level is at a maximum.

Actual yields are not presented, because usually they show wide variation. Here we suffice with the observation that in practice they may vary from very low on 
soils hardly suitable for agriculture, to very high in the newly reclaimed IJsselmeer polders. In these potato and beet crops almost potential growth rates are attained during the period of a closed green leaf canopy. The data of Bodlaender \& Algra (1966) and de Vos (1977) show that the calculated annual yields can actually be attained.

Table 2 records of the control plot (PI-) of sugar-beets an average 24 tons of dry matter in total for the last two yields. In Table 1 the total dry matter yield of sugar-beets was calculated to be $25150 \mathrm{~kg}$. This proves that the actual yields are almost equal to the calculated ones. In fresh weight of beets the calculated amount of beets is $76590 \mathrm{~kg} \mathrm{ha}^{-1}$. In the field experiment some $80000 \mathrm{~kg} \mathrm{ha}^{-1}$ was recorded. This was also due to a more favourable ratio foliage: beet than was assumed in the calculations. These high yields have also been caused by the radiant weather in 1976 (Sibma, 1970).

A frequently heard question is to what extent early spring development may affect the yield potential. This aspect is difficult to measure in experiments, because in that case varieties have to be used that differ in earliness. However, when varieties are compared that differ in earliness, it is possible that this earliness is genetically associated with other properties, and therefore the advantage of earliness cannot be inferred from the ultimate yield. By accelerating one group of plants of the same variety in spring, without changing other properties, a distinct idea can be formed of the advantage of a crop with a closed canopy early in spring. The experiments give evidence enough that only acceleration of the initial growth will have effects

Table 2. Comparison of dry matter yields of maize and sugar-beets grown under plastic until some weeks after emergence $(\mathrm{P} 1+)$ and control $\mathrm{P} 1-)$.

\begin{tabular}{|c|c|c|c|c|c|c|c|c|c|}
\hline \multirow{2}{*}{$\begin{array}{l}\text { Exp. } \\
\text { No. }\end{array}$} & \multirow[t]{2}{*}{ Year } & \multirow[t]{2}{*}{ Crop } & \multirow[t]{2}{*}{ Cultivar } & \multirow{2}{*}{$\begin{array}{l}\text { Harvest } \\
\text { date }\end{array}$} & \multirow{2}{*}{\multicolumn{2}{|c|}{ Treatment }} & \multicolumn{3}{|c|}{ Yield in $\mathrm{kg} \mathrm{dm} \mathrm{ha}{ }^{-1}$} \\
\hline & & & & & & & $\begin{array}{l}\text { main } \\
\text { product }\end{array}$ & $\begin{array}{l}\text { additional } \\
\text { product }\end{array}$ & total \\
\hline \multirow[t]{4}{*}{ IBS 1805} & 1975 & Maize & Capella & 28 aug. & Sown & $\mathbf{P l}+$ & 6250 & 9330 & 15580 \\
\hline & & & & & & $\mathrm{Pl}$ & 3880 & 9460 & 13340 \\
\hline & & & & & Planted & $\mathrm{Pl}+$ & 6250 & 9750 & 16000 \\
\hline & & & & & & $\mathrm{Pl}-$ & 4110 & 9950 & 14060 \\
\hline \multirow[t]{8}{*}{ CABO 30} & 1976 & Maize & Capella & 21 Sept. & & $\mathbf{P l}+$ & 9490 & 12640 & 22120 \\
\hline & & & & & & $\mathrm{Pl}-$ & 8150 & 13480 & 21630 \\
\hline & & & P 3853 & 21 Sept. & & $\mathrm{PI}+$ & 8460 & 16870 & 25330 \\
\hline & & & & & & $\mathrm{Pl}-$ & 5060 & 15840 & 20900 \\
\hline & & & Capella & 15 Oct. & & $\mathbf{P l}+$ & 12330 & 10318 & 22648 \\
\hline & & & & & & $\mathrm{Pl}-$ & 9710 & 8694 & 18404 \\
\hline & & & P 3853 & 15 Oct. & & $\mathbf{P l}+$ & 11760 & 11984 & 23744 \\
\hline & & & & & & $\mathrm{Pl}-$ & 9970 & 11966 & 21936 \\
\hline \multirow[t]{4}{*}{ CABO 31} & 1976 & Sugar- & Monohil & 121 Sept. & & $\mathrm{Pl}+$ & 19480 & 6400 & 25880 \\
\hline & & beets & & & & $\mathrm{Pl}-$ & 17320 & 6460 & 23780 \\
\hline & & & & 12 Oct. & & $\mathrm{Pl}+$ & 19460 & 5980 & 25440 \\
\hline & & & & & & $\mathrm{Pl}-$ & 18040 & 6372 & 24440 \\
\hline
\end{tabular}


as to be expected from the calculations. The period between emergence and the time of a closed leaf canopy was shortened some 10 days by the plastic covers. The result of this acceleration of 10 days should have to be $10 \times 200 \mathrm{~kg}$ dry matter. Table 2 shows that the yield increases are indeed in this order of magnitude.

For plant breeding this is evidence that acceleration in maize and sugar-beets is of distinct advantage to the yields. Finally, we point out that we do not think that practical application of the plastic tunnels as in our experiments will be profitable in agriculture.

\section{References}

Alberda, Th. et al., 1977. Crop photosynthesis: methods and compilation of data obtained with a mobile field equipment. Agric. Res. Rep. 865: 22-30.

Bodlaender, K. B. A. \& S. Algra, 1966. Influence of the growth retardant B 995 in growth and yield of potatoes. Eur. Potato J. 9: 242-258.

Burton, W. G., 1964. The respiration of developing potato tubers. Eur. Potato J. 7: 90-99.

Houba, V. J. G., 1973. Effect of nitrogen dressings on growth and development of sugar beet. Agric. Res. Rep. 791: 1-65.

Jonker, J. J., 1958. Bewortelingsonderzoek en ondergrondbewerking in de Noordoostpolder. Thesis, Agricultural University Wageningen, or 'Van zee tot land' No 25: 1-164.

Louwerse, W. \& J. W. Eikhoudt, 1975. A mobile laboratory for measuring photosynthesis and transpiration of field crops. Photosynthetica 9: 31-34.

Rijtema, P. \& G. Endrödi, 1970. Calculation of production of potatoes. Neth. J. agric. Sci. 18: 26-36.

Sibma, L., 1970. Relation between total radiation and yield of some field crops in the Netherlands. Neth. J. agric. Sci. 18: 125-131.

Vos, N. M. de, 1977. Potential and actual yields of cereals especially winter wheat. (In press).

Winkler, E., 1970. Kartoffelbau in Tirol. II. Photosynthesevermögen und Respiration von verschiedenen Kartoffelsorten. Potato Res. 14: 1-18.

Wit, C. T. de, 1965. Photosynthesis of leaf canopies. Agric. Res. Rep. 663: 1-57.

Wit, C. T. de, 1975. Substitution of labour and energy in agriculture and options for growth. Neth. J. agric. Sci. 23: 145-162.

Zachariasse, L. C., 1974. Boer en bedrijfsresultaat. Publ. Afd. agr. Bedrijfsecon. LandbHogesch. Wageningen No 8: 1-113.

Zweerde, H. van der, 1968. Wortel- en stoppelresten bij gemaaidorste granen. Jaarb. Inst. biol. scheik. Onderz. LandbGewassen: 11-15. 